A SHORT COURSE ON FUNCTIONAL EQUATIONS 


\section{THEORY AND DECISION LIBRARY}

\section{General Editors: W. Leinfellner and G. Eberlein}

Series A: Philosophy and Methodology of the Social Sciences

Editors: W. Leinfellner (University of Nebraska)

G. Eberlein (University of Technology, Munich)

Series B: Mathematical and Statistical Methods

Editor: H. Skala (University of Paderborn)

Series C: Game Theory and Decision Making

Editor: S. Tijs (University of Nijmegen)

Series D: System Theory, Knowledge Engineering and Problem Solving

Editor: W. Janko (University of Vienna)

\section{SERIES B: MATHEMATICAL AND STATISTICAL METHODS}

Editor: H. Skala (Paderborn)

\section{Editorial Board}

J. Aczel (Waterloo), G. Bamberg (Augsburg), W. Eichhorn (Karlsruhe),

P. Fishburn (New Jersey), D. Fraser (Toronto), B. Fuchssteiner (Paderborn), W. Janko (Vienna), P. de Jong (Vancouver), M. Machina (San Diego),

A. Rapoport (Toronto), M. Richter (Aachen), D. Sprott (Waterloo),

P. Suppes (Stanford), H. Theil (Florida), E. Trillas (Madrid), L. Zadeh (Berkeley).

\section{Scope}

The series focuses on the application of methods and ideas of logic, mathematics and statistics to the social sciences. In particular, formal treatment of social phenomena, the analysis of decision making, information theory and problems of inference will be central themes of this part of the library. Besides theoretical results, empirical investigations and the testing of theoretical models of real world problems will be subjects of interest. In addition to emphasizing interdisciplinary communication, the series will seek to support the rapid dissemination of recent results. 


\section{J. ACZÉL}

Centre for Information Theory,

University of Waterloo, Ontario, Canada

\section{A SHORT COURSE ON FUNCTIONAL EQUATIONS}

Based Upon Recent Applications to the Social and Behavioral Sciences

\section{REIDEL PUBLISHING COMPANY}

A MEMBER OF THE KLUWER 
Library of Congress Cataloging in Publication Data

Aczél, J.

A short course on functional equations.

(Theory and decision library. Series B, Mathematical and statistical methods)

Bibliography: $p$.

Includes indexes.

1. Economics, Mathematical. 2. Functional equations. 3. Social sciences-Mathematics. I. Title. II. Series.

HB135.A28 $1987 \quad 515^{\prime} .25 \quad 86-26131$

ISBN-13: 978-90-277-2377-2 e-ISBN-13: 978-94-009-3749-9

DOI: $10.1007 / 978-94-009-3749-9$

Published by D. Reidel Publishing Company,

P.O. Box 17, 3300 AA Dordrecht, Holland.

Sold and distributed in the U.S.A. and Canada

by Kluwer Academic Publishers,

101 Philip Drive, Assinippi Park, Norwell, MA 02061, U.S.A.

In all other countries, sold and distributed

by Kluwer Academic Publishers Group,

P.O. Box 322, 3300 AH Dordrecht, Holland.

All Rights Reserved

(C) 1987 by D: Reidel Publishing Company, Dordrecht, Holland

Softcover reprint of the hardcover 1st edition 1987

No part of the material protected by this copyright notice may be reproduced or

utilized in any form or by any means, electronic or mechanical

including photocopying, recording or by any information storage and retrieval system, without written permission from the copyright owner 


\section{TABLE OF CONTENTS}

$\begin{array}{ll}\text { Introduction } & 1\end{array}$

Section 1.

An aggregation theorem for allocation problems. Cauchy equation for single- and multiplace functions. Two extension theorems.

\section{Section 2.}

Scale-invariant equal sacrifice in taxation. The linear-affine functional equation. Multiplicative and logarithmic functions.

\section{Section 3.}

General forms of 'laws of sciences' without dimensional constants. The case of the same ratio scale for all variables. Generalized homogeneous functions. Inequality measures.

\section{Section 4.}

General forms of 'laws of science' with (partially) independent ratio and interval scales. Multiplace multiplicative and logarithmic functions. Price levels. Endomorphisms of a real field. The exponential equation. Characters.

\section{Section 5.}

Pexider's equation and its extension. Quasi-extension of Cauchy's equation. Determination of all generalized Hicks-neutral production functions.

\section{Section 6.}

Determination of all Hicks-neutral production functions depending upon capital, labor and time (state of technology). The translation equation. 
Section 7.

The associativity equation. Synthesis of ratio judgements. The quasiarithmetic means. The Jensen equations. A conditional linear-affine equation. A characterization of root-mean-powers and of the geometric mean.

Section 8.

Synthesis of measure judgements. Equations in a single variable.

The Abel and Schröder equations. Iteration.

References

Subject index

Index of names 